\title{
An Assessment of the Effect of Mass Media Platforms and County Assembly Initiatives on Public Participation in Kitui County
}

\author{
Kasina Musunza ${ }^{1}$ and Wilson Muna ${ }^{2}$ \\ ${ }^{1,2}$ Department of Public Policy \& Administration, Kenyatta University, Kenya
}

\begin{abstract}
Devolution entails the decentralization of power and distribution of resources from the national government to the county governments. To ensure that national and county governments are providing good governance, public participation is vital. Studies done indicate that there is no information pertaining to devolution, county governments, and public participation in the Kenyan county governments. In this study, Kitui county has been used to assess the county assembly initiative and the mass media initiative and their effectiveness in encouraging public participation. The exploratory research design was used to collect data from the target population of Kitui Central Sub County. Data was collected from 100 respondents using structured questionnaires. From the results received, it is evident that Kitui County Government has taken steps to enhance public participation by implementing Mass Media initiatives and County Assembly initiatives. Although, most of the respondents saw the need for the county government to put in more effort to ensure that the public is involved in governance, establishing efficient and effective public engagement initiatives will help strengthen public participation in devolved structures.
\end{abstract}

Key Words: Public Participation, County Assembly, Mass Media, Policy, Devolution

DOI 10.35942/ ijcab.v5i2.171

\section{Cite this Article:}

Musunza, K., \& Muna, W. (2021). An Assessment of the Effect of Mass Media Platforms and County Assembly Initiatives on Public Participation in Kitui County. International Journal of Current Aspects, 5(2), 50-55. https://doi.org/10.35942/ijcab.v5i2.171

\section{Introduction}

According to Odhiambo and Taifa (2009), public participation entails having all stakeholders in the community involved in development initiatives and decision-making processes that affect them. The stakeholders influence policy formulation, investment choice, management decisions, and alternative design. In most developed nations, public participation is a legal requirement in running national and local governments. It improves service delivery, brings the people closer to the government, and ensures accountability by local governments (A and D, 2008). Public involvement is vital in running any government institution since research shows that it brings a sense of belonging. Normally, people would reject new ideas imposed on them, however, involving them in making new choices will help meet their needs since marginalized people can air their views freely, hence bringing about sustainable ideas (Mwendwa, 2017).

Even though public participation is essential in running governments, an information gap on public participation and its implementation in county governments still exists. In 2012, a baseline report on governance status revealed that only $29 \%$ of the population understood devolution and how it was structured in their local governments and $24.7 \%$ understood how devolved governments worked (Finch and Omolo, 2015; Lewis, 2015). Less than one percent of the public had participated in county development policies that affected them. Also, most of the interviewees said 
that most of their preferences were on voting and electing their leaders and no other county functions (Society for International Development, 2012). It is evident that even though Kenya is a devolved country, public participation is not being implemented in ensuring good governance. According to the 2010 Kenyan Constitution, public engagement is supposed to be the pillar in running county governments (Lewis, 2015). The negligence of public involvement by county governments led to carrying out this research, aiming at finding out the effectiveness of County Assembly Initiatives and Mass Media initiatives in promoting public engagement in Kenyan County Governments. The study is based on the fact that little information on the topic exists despite its importance in ensuring good leadership. The study focuses on Kitui Central Subcounty in Kitui County.

\section{Literature Review}

\subsection{The role of Mass Media in Enhancing Public Engagement}

Mass media plays a significant part in shaping public attitude and public opinion and encouraging societal change. In the contemporary world, mass media has set its place in society, becoming the fourth estate. It has various communication forms and channels (television, radio, newspapers, cinema, internet websites, and magazines) that educate the public and create awareness on important issues in the community (Johnson, 2010). The varied forms of communication play a significant role in the community and can be used to convey specific information to specific societal groups through customization (Mwendwa, 2017). Through mass media, people connect with others around them or even in far regions, especially through the internet. People's perceptions and thoughts on various matters are framed by the media (Dyer, 2008). Mass media acts as a protector of the public's interests, a bridge between the people and the government, and a people's watchdog. It also informs the public on daily occurrences such as sting operations, natural hazards, and terrorist attacks, hence creating public awareness. The media's key objective should be informing, entertaining, and educating the public. Its communication forms should be designed in a manner that brings society together and promotes unity (Wekesa, 2012). Looking at all the benefits mass media brings to society; Kenyan county governments must declare it an instrument and pillar that needs to be embraced and maintained to enhance public involvement in local governments. Mass media platforms that can be used are; social media, live platforms, publications, and websites (Kimathi, 2017).

\subsection{The Role of County Assembly in Promoting Public Involvement}

Once the 2010 Kenyan Constitution was promulgated, the national government moved most of the decision-making processes to the county governments. The constitution made it clear that the objective of bringing devolution was to encourage public participation by ensuring accountability, transparency, and responsibility in county functions where citizens can share their views and interact, hence framing the public decision-making process (Roe, 2008). In the national governments, the national assembly (parliament) is responsible for public participation whereas at the county level it is the responsibility of the county assembly. The 2010 constitution has listed provision on how public involvement is to be done, however, the provisions cannot be applied at the county level since its ideas are new, and most counties face challenges in implementing them (Mwendwa, 2017). For example, county governments have no organ set aside to guarantee public participation. Different countries use different styles in involving their citizens which leads to congruence and disharmony (Kimathi, 2017). The public is not aware that they are needed in many other functions other than voting. County assemblies must come up with strategies that can educate 
the public on their role in policy formulation and legislation. With no county assembly initiatives in place, public participation will never be practised in Kenyan counties. The media will claim that the government is not willing to cooperate, and that will not create a good image of the government (Bichou and Gray, 2006). Therefore, county assemblies are the key drivers of public involvement in good governance. They can implement initiatives such as inter-county benchmarking, conferences, county public participation bills, and committee reports to improve the people's involvement in policymaking and legislation.

\section{Methodology}

\subsection{Research Methods}

The research method employed was exploratory research design as it provides a basis for easy understanding of the topic being researched (Wekesa, 2012). By applying the research method, a hypothesis on public participation in county governance was established. The targeted population was the people of Kitui Central Sub County with citizens above 18 years old. The participants were five MCAs (Member of the County Assembly), five Ward Administrators, eighty members of the public, and ten village administrators. A formula by Mugenda and Mugenda was used to arithmetically select one hundred individuals from the 70,736 registered voters in the region. Random sampling that is systemically stratified was used to select the respondents since different categories of people were needed in the research.

\subsection{Data Collection and Analysis}

Structured questionnaires were used to collect data. They were hand-delivered to the respondents, and the research went to pick them later once filled. Research assistants were available to sis in the distribution, filling, and collection processes in the villages since the population here is made up of mostly uneducated people.

Descriptive analysis was done on the quantitative data, which included the calculation of means, frequencies, and percentages. A thematic process was used in analysing qualitative data that came up when carrying out the interviews. The project findings were then tabulated and also presented in charts. Tables and charts made it easier to analyse and compare responses. Graphics and direct quotations have been used to display the findings of the qualitative data.

\section{Results and Discussion}

\subsection{Mass Media Initiatives}

The variable for assessing the effectiveness of mass media in encouraging public participation was Kitui county government's implementation of mass media in promoting public involvement as shown in Table 1 below;

Table 1: Mass Media Initiatives Frequency

\begin{tabular}{|c|c|c|c|c|c|}
\hline Mass Media Initiatives & 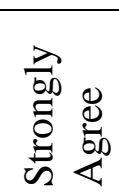 & 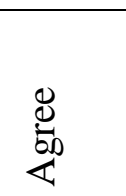 & $\begin{array}{l}\bar{\pi} \\
\vdots \\
0 \\
0 \\
Z\end{array}$ & 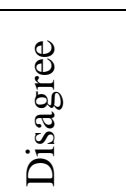 & 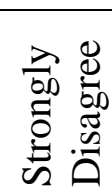 \\
\hline $\begin{array}{l}\text { Kitui County uses mass media initiatives such as } \\
\text { social media and live forums }\end{array}$ & $\begin{array}{l}4 \\
(4 \%)\end{array}$ & $\begin{array}{l}18 \\
(18 \%)\end{array}$ & $\begin{array}{l}29 \\
(29 \%)\end{array}$ & $\begin{array}{l}45 \\
(45 \%)\end{array}$ & $\begin{array}{l}4 \\
(4 \%)\end{array}$ \\
\hline
\end{tabular}




\begin{tabular}{|c|c|c|c|c|c|}
\hline Mass Media Initiatives & 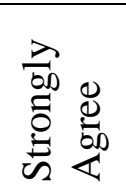 & 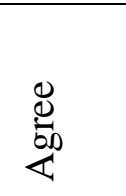 & 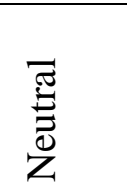 & 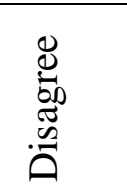 & 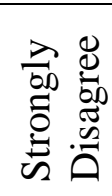 \\
\hline $\begin{array}{l}\text { Mass Media services by disseminating } \\
\text { information improved efficiency in conveying } \\
\text { information }\end{array}$ & $\begin{array}{l}9 \\
(9 \%)\end{array}$ & $\begin{array}{l}44 \\
(44 \%)\end{array}$ & $\begin{array}{l}29 \\
(29 \%)\end{array}$ & $\begin{array}{l}15 \\
(15 \%)\end{array}$ & $\begin{array}{l}3 \\
(3 \%)\end{array}$ \\
\hline $\begin{array}{l}\text { Mass media initiatives enhance the efficiency of } \\
\text { public governance significantly }\end{array}$ & $\begin{array}{l}33 \\
(33 \%)\end{array}$ & $\begin{array}{l}32 \\
(32 \%)\end{array}$ & $\begin{array}{l}18 \\
(18 \%)\end{array}$ & $\begin{array}{l}13 \\
(13 \%)\end{array}$ & $\begin{array}{l}4 \\
(4 \%)\end{array}$ \\
\hline $\begin{array}{l}\text { Mass media initiatives the county's reach in } \\
\text { empowerment, citizen engagement, and } \\
\text { communication }\end{array}$ & $\begin{array}{l}26 \\
(26 \%)\end{array}$ & $\begin{array}{l}55 \\
(55 \%)\end{array}$ & $\begin{array}{l}15 \\
(15 \%)\end{array}$ & $\begin{array}{l}2 \\
(2 \%)\end{array}$ & $\begin{array}{l}2 \\
(2 \%)\end{array}$ \\
\hline $\begin{array}{l}\text { Kitui county government uses mass media to } \\
\text { connect with its people }\end{array}$ & $\begin{array}{l}44 \\
(44 \%)\end{array}$ & $\begin{array}{l}48 \\
(48 \%)\end{array}$ & $\begin{array}{l}6 \\
(6 \%)\end{array}$ & $\begin{array}{l}1 \\
(1 \%)\end{array}$ & $\begin{array}{l}1 \\
(1 \%)\end{array}$ \\
\hline $\begin{array}{l}\text { The Implementation of mass media initiatives is } \\
\text { effective in getting to a large number of the } \\
\text { population }\end{array}$ & $\begin{array}{l}39 \\
(39 \%)\end{array}$ & $\begin{array}{l}53 \\
(53 \%)\end{array}$ & 0 & 0 & $\begin{array}{l}8 \\
(8 \%)\end{array}$ \\
\hline
\end{tabular}

Quantitative data regarding mass media initiatives implementation and its effectiveness in promoting the people's involvement in county governance was collected from the structured part of the questionnaires. Feedback received from the five questions on mass media initiatives had a standard deviation of 0.388 and a mean of 3.76. The results indicate that majority of the interviewees agreed that mass media initiatives enhanced public engagement in local governments. A Kruskal-Wallis rank test was used to find out whether different respondents had different perceptions on the role of mass media in encouraging public engagement in county governments. The difference in people's perception towards the role of mass media in county governments was significant (Kruskal-Wallis $\mathrm{H}=9.291, \mathrm{p}=0.026$, and $\mathrm{df}=3$ ). Ward administrators held the highest mean, followed by MCAs, then the public. The results indicate that MCAs, members of the public, and ward administrators believe that mass media influences public engagement in the counties.

\subsection{County Assembly Initiatives}

The result from the determination of the part played by the Kitui County Assembly in promoting public participation are indicated in Table 2 below;

Table 2: County Assembly Initiatives Frequency

\begin{tabular}{|c|c|c|c|c|c|}
\hline County Assembly Initiatives & 常 & 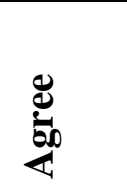 & Z゙ & 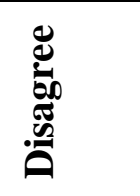 & 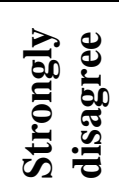 \\
\hline $\begin{array}{l}\text { Members of the County Assembly are aware } \\
\text { that they are required by the constitution to } \\
\text { adopt and promote public participation }\end{array}$ & $\begin{array}{l}16 \\
(16 \%)\end{array}$ & $\begin{array}{l}54 \\
(54 \%)\end{array}$ & $\begin{array}{l}18 \\
(18 \%)\end{array}$ & $\begin{array}{l}10 \\
(10 \%)\end{array}$ & $\begin{array}{l}16 \\
(16 \%)\end{array}$ \\
\hline $\begin{array}{l}\text { The county assembly is fully engaged in issues } \\
\text { affecting service delivery and governance }\end{array}$ & $\begin{array}{l}20 \\
(20 \%)\end{array}$ & $\begin{array}{l}64 \\
(64 \%)\end{array}$ & $\begin{array}{l}10 \\
(10 \%)\end{array}$ & $4(4 \%)$ & $\begin{array}{l}2 \\
(2 \%)\end{array}$ \\
\hline
\end{tabular}




\begin{tabular}{|c|c|c|c|c|c|}
\hline County Assembly Initiatives & 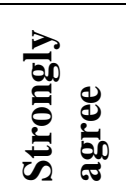 & 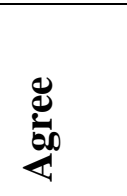 & 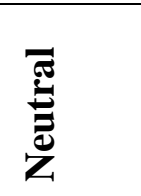 & 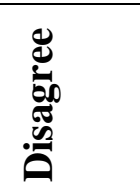 & 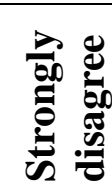 \\
\hline $\begin{array}{l}\text { The county assembly committee considers the } \\
\text { people's opinions }\end{array}$ & $\begin{array}{l}16 \\
(16 \%)\end{array}$ & $\begin{array}{l}69 \\
(69 \%)\end{array}$ & $\begin{array}{l}13 \\
(13 \%)\end{array}$ & $2(2 \%)$ & 0 \\
\hline $\begin{array}{l}\text { There are bills put in place by the county } \\
\text { assembly on public involvement }\end{array}$ & $\begin{array}{l}8 \\
(8 \%)\end{array}$ & $\begin{array}{l}78 \\
(78 \%)\end{array}$ & $\begin{array}{l}10 \\
(10 \%)\end{array}$ & 0 & $\begin{array}{l}4 \\
(4 \%)\end{array}$ \\
\hline $\begin{array}{l}\text { The county held workshops, benchmarking } \\
\text { trips, and seminars }\end{array}$ & $\begin{array}{l}25 \\
(25 \%)\end{array}$ & $\begin{array}{l}66 \\
(66 \%)\end{array}$ & $6(6 \%)$ & $2(2 \%)$ & $\begin{array}{l}1 \\
(1 \%)\end{array}$ \\
\hline
\end{tabular}

The feedback from the five questions posed in the determination of the role of the Kitui County Assembly in promoting public engagement had a mean of 3.938 and a standard deviation of 0.328 . The results indicate that respondents believe that initiatives put in place by the county assembly to promote public participation are helpful. Kruskal-Wallis $\mathrm{H}$ test was used to determine whether respondents held varying views on the effectiveness of the county assembly in promoting public engagement in local governments (Iberi, 2014). The difference between people's perceptions was significant on the rile of the county assembly on public involvement $\left(\left(X^{2}(3)=9.107, p=.028\right)\right.$. Village administrators held the highest rank (74.45), then MCAs with 58.30, ward administrators had 56.30, whereas the public had 46.66. The results show that the public and wards administrators did not believe that county assembly initiatives were effective as much as the MCAs and village administrators did. The results also indicate that county assembly initiatives towards public participation are in place in Kitui County. According to interviewees, Kitui County Government has put in efforts to ensure public involvement in governance. "The public is allowed to witness county legislative processes in the county assembly" [R5]. "not much has been done in this devolved government...we can only witness the processes but cannot actively participate" [R30]. "You can share your comments of ideas to the county...for me, that is participation" [R19]. The majority of the respondents believed that the county assembly was making efforts to improve public involvement in governance. Devolution comes with benefits that need to improve people's lives, hence the need for their participation (Ngigi and Busolo, 2019; Muriuki, 2012).

\section{Conclusion}

To enhance public participation in devolved governments, the county assembly and mass media play a significant role. From the study, county assembly initiatives and mass media initiatives put in place by the county government of Kitui have proven to be effective. MCAs and ward administrators have supported the initiatives put in place to encourage people to take part in policy legislation and decision-making processes that affect them in the county. However, much has to be done to ensure there is a continuous commitment. It can be done by implementing interventions like, live forums, publications, and social media. Suggestions and opinions from the people can then be used to make decisions and legislate policies. In reviewing the role of the county assembly, there are efforts put in place such as enacting public participation bills, benchmarking, and workshops. However, the strategies have not been fully implemented. The County assembly needs to take a stand and remain firm when holding public participation forums to improve governance.

\section{References}

A. , B. , \& D, C. (2008). Introduction to Qualitative Research. London: Oxford University Press. 
Bichou, R. , \& Gray. (2006). A logistics and Supply Chain management Approach to Port Performance Measurement.

Dyer, G. (2008). Advertising as communication. Routledge.

Finch, C., \& Omolo, A. (2015). Building Public Participation in Kenya's Devolved Government. World Bank Group, Washington, DC. (C) World Bank. https://openknowledge.worldbank.org/handle/10986/21663 License: CC BY 3.0 IGO.

Iberi, D. (2014). Print Media Coverage Of County Governance In Kenya: A Content Analysis Of The Daily Nation And The Standard Newspapers. A Research Project Submitted To The University Of Nairobi, School Of Journalism And Mass Communication In Partial Fulfillment Of The Requirements For The Degree Of Master Of Arts In Communication Studies. $\quad$ Retrieved from http://erepository.uonbi.ac.ke/bitstream/handle/11295/76290/Iberi_Print\%20media\%20 coverage $\% 20$ of $\% 20$ county $\% 20$ governance $\% 20 \mathrm{in} \% 20$ Kenya.pdf?sequence $=3 \&$ isAllow $\mathrm{ed}=\mathrm{y}$

Johnson, T. (2010). Environmentalism and NIMBYism in China: promoting a rules-based approach to public participation. Environmental Politics, 19 (3), 430-448.

Kimathi, L. (2017). Challenges of the Devolved Health Sector in Kenya: Teething Problems or Systemic Contradictions? Africa Development, 42 (1), 55-77.

Lewis, S. (2015). Qualitative inquiry and research design: Choosing among five approaches. Health promotion practice, 16.

Mwendwa, C. G. (2017). Analysis of Communication Channels Used In The Educational Book Publishing Industry In Kenya. A Research Project Submitted in Partial Fulfillment for

The Award of a Masters of Arts Degree in Communication Studies, School of Journalism and Mass Communication University of Nairobi. Retrieved from http://journalism. uonbi. ac. ke/sites/default/files/chss/journalism/journalism/GITONGA\%20CAROLINE\%20MW ENDWA\%20project. Pdf

Muriuki, m. J. (2012). Right to public participation in devolved governance in kenya; a myth or a reality (doctoral dissertation, university of nairobi).

Odhiambo, M. , \& Taifa, A. (2009). 'Devolved Funds Development'. A Handbook on Participation. Claripress. Nairobi: .

Roe, D. N. (2008). Community management of natural resources in Africa: Impacts, experiences and future directions (No. 18). IIED.

Society for International Development. (2012). The Status of Governance in Kenya. Baseline Survey Report. Retrieved from

https://www.sidint.net/sites/www.sidint.net/files/docs/Governance_Report.pdf

Wekesa, S. M. (2012). 'County Governments and Rights of Marginalized Ethnic Minorities in Kenya: Evaluating the Potential Benefits and Challenges of Devolution' . LLM Dissertation, University of Pretoria .

This is an open-access article published and distributed under the terms and conditions of (c) (†) (8)

the Creative Commons Attribution 4.0 International License of United States unless otherwise stated. Access, citation and distribution of this article is allowed with full recognition of the authors and the source. Authors seeking to publish with an Internationally Peer Reviewed Journals should consider https://www.ijcab.org/ by writing to the Editor at editor@ijcab.org or submitting online at https://journals.ijicab.org/journals/index.php. The articles must be quality and meet originality test. 
International Journal of Current Aspects, Volume 5, Issue 2, May 2021, PP 50-55, ISSN 2616-6976 [JCAB

$\frac{\text { IJCAB }}{\text { Publishing Group }}$ 